\title{
11. Enacting immigration politics in a juridical register
}

\author{
Leila Kawar and Jonathan Miaz
}

\section{INTRODUCTION}

Immigration is undoubtedly a hot topic for legal scholars and practitioners, and immigrant rights has recently been identified as "the civil rights issue of our time" (Gambino 2018). Indeed, it is not difficult to see parallels between immigrant rights advocacy today and earlier iconic rights-based mobilizations. Turning to these earlier models of political mobilization, undocumented immigrants and asylum seekers have staged sit ins and other actions that risked arrest in order to protest the unresponsiveness of elected officials towards their cause. In a number of countries, migrants and their supporters have looked to the courts for principled decisions defending the rights of asylum seekers and other vulnerable migrants, hoping that legal mobilization might be an avenue to propel policy change.

In practice, however, judicially-enunciated rules seldom substitute for regulation by the political branches of government on immigration questions. A tendency towards judicial deference has been amply documented across a range of national and supranational jurisdictions on immigration matters (Dembour 2015; Hailbronner 2007; Hansen et al. 2000; Hailbronner 1998; Glenn 1991; Neuman 1990). Moreover, as demonstrated by the rich and growing literature on the comparative politics of immigration, the contentious nature of immigration and asylum policymaking undercuts efforts to extend doctrinal logic and symmetry within this domain of law (Money 2018). Particularly in countries with high levels of irregular migration, the frequency of legislative interventions and the flux in administrative policymaking combine to create a legal environment in which there is little room for the development of formalist jurisprudence.

Rather than avoiding or circumventing this entanglement of law with politics in the immigration domain, our empirical approach explicitly directs attention to the policymaking dynamics that this entanglement of law and politics sets in motion. Drawing on social science scholarship that conceptualizes the judicialization of public policy matters through a relational lens (Rayner and Voutat 2014; Doumoulin and Roussel 2010), we approach the contestation of immigration and asylum policy questions as a culturally productive process that engages not only courts and legislatures but also a range of other kinds of actors. One insight generated from approaching the judicialization and juridification of immigration matters as a culturally

1 Some elements of the discussion of the US and France in this chapter draw from or expand upon material found in Kawar (2015). Financial support for research in the US and France was provided by a grant from the National Science Foundation (NSF-SES-0626797). The elements of the discussion of the Swiss case in this chapter draw from or expand upon material found in Miaz (2017a). Financial support for research on Switzerland was provided by an Early Postdoc. Mobility fellowship of the Swiss National Science Foundation (SNF). The research would not have been possible without the generous assistance of many respondents in the US, France, and Switzerland. 
productive process is that repeated engagement with courts can have radiating policy effects even when immigration jurisprudence remains relatively undeveloped doctrinally (Kawar 2015). Building on this approach, the comparative analysis in this chapter identifies three different registers through which judicialized immigration policymaking has been enacted.

This empirical analysis of judicialization's differing registers draws on semi-structured interviews - with administrative officials, judges, and immigrant rights advocates - generated by multi-year fieldwork studies conducted in the US and France and in Switzerland respectively. ${ }^{2}$ Focusing on the shared repertoires held by our respondents allows us to delve deeply into the informal protocols and local meanings through which legal referents are deployed in immigration policymaking. Methodologically, our starting point is that these meanings developed by various actors engaged in the implementation of law are most usefully conceptualized, not as perversions of formalist ideals, but rather as continuing the process of policy and lawmaking "on the ground". ${ }^{3}$ Moreover, our analysis in this chapter leverages a comparative optics to lift up the distinct interactive registers of judicialized immigration politics at work in our research settings. This method for using comparison to interrogate the distinct register of a given field of law-in-action takes its inspiration from cultural studies of scientific expertise, which have investigated how different domains of knowledge-production acquire and retain particular cultural characteristics (Parthasarathy 2017; Knorr Cetina 1999; Traweek 1992). Extending this approach to judicialized knowledge-production in our three nationally-bounded settings, we explore not only how the practices of immigrant advocates and administrative actors are patterned by engagement with courts, but also the local ontologies that emerge from context-specific processes of judicialization.

We see our approach as closely aligned with the tradition of New Legal Realism and its commitment to contextually-sensitive and theoretically-informed empirical study. Our analysis examines how routinized legal contestation varies in register across contexts, while emphasizing that these multi-layered juridical assemblages are difficult to reduce to determinate variables - whether doctrinal, political, or institutional - of the sort required for positivist prediction. Not only are these registers multi-dimensional and inseparable from local and historical context, but their lived enactment, the interactive performance of turning to law, is itself constitutive of the constellation of roles and interests that participants in each setting recognize and find meaningful. An approach that focuses on the interactive performance of turning to law thus aligns with the interdisciplinary and pragmatist orientation of New Legal Realist scholarship (Tamanaha 2017; Nourse and Shaffer 2009; Erlanger et al. 2005). Our analysis takes formal law seriously, in the sense that it attends to how actors on the ground engage with doctrinal forms in the process of constructing law's meaning. At the same time, shifting the focus from the rules and outcomes of litigation to the interactive enactment of judicialized policymaking offers resources for scholars and advocates seeking to better understand widely shared yet often taken-for-granted aspects of immigration policymaking. This type of analysis

2 Author Leila Kawar conducted 93 interviews between 2005 and 2014 in the US and France. Author Jonathan Miaz conducted 99 interviews (59 in the administration, 34 with attorneys, lawyers and activists defending asylum seekers, and six with judges and law clerks) between 2011 and 2019 in Switzerland.

3 This is a longstanding theme in comparative studies of law and policy, one that is present in both English-language and French-language scholarship (see Gessner and Thomas 1988; Lascoumes 1990). A somewhat similar focus is found in studies of street-level bureaucracy (see, e.g., Brodkin 2013; Lipsky 2010). 
also calls attention to the role of law reform efforts in constructing these culturally productive processes.

In what follows, we begin by presenting our three case studies from the US, France, and Switzerland. In each setting, we first briefly outline the political and legal ecology in which advocates invoke judicial oversight of immigration and asylum policymaking and then develop an account of the distinct juridical registers instantiated through these interactive processes of legal invocation and mobilization. After discussing each setting in turn, we then work across the studies to evaluate the implications of these findings for legal practitioners who engage in asylum casework, deportation defense litigation, and other forms of immigration-related legal practice.

\section{THE PERFORMANCE OF JUDICIALIZED POLITICS IN THE UNITED STATES}

Since the 1970s, a network of immigration-focused national legal organizations has regularly coordinated litigation aiming to influence immigration and asylum policymaking. These litigation efforts draw on a broader tradition of civil rights and public interest lawyering that shapes lawyers' professional identities and provides an organizational model for their mobilizations of law (Kawar 2011, 363-371; Cummings 2007; Coutin 2006). At the same time, these legal mobilizations face the continued legal authority of the 19th century Plenary Power Doctrine, mandating judicial deference to the legislative and executive branches. Although US courts have shown a willingness to apply a subconstitutional analysis informed by constitutional equal protection and due process principles, they generally decline to exercise constitutional judicial review in immigration policy matters (Motomura 1990). As a result, lower federal courts typically offer a more conducive forum for immigrant defenders, as their fact-centered review of administrative practice is relatively less attuned to paradigms of sovereign authority (Law 2010).

In this context, US lawyers seeking to use litigation to influence immigration policymaking have gravitated towards regular reliance on class action litigation targeting administrative practices. Courts hearing these cases have the authority to issue consensual remedial decrees and permanent injunctions against agency practices even without a showing that these resulted from a formal policy. Legal activists learned through experience that it was not particularly difficult to use class action lawsuits to convince courts that administrative officials were acting abusively, particularly when federal agencies were under-resourced and vulnerable to political influence (Morris 1984). In terms of the substantive immigration policies that became the target for class action litigation, legal contestation over the past 40 years has repeatedly challenged aspects of asylum processing and detention practices applied to migrants fleeing conflict in Central America. During this period, concerted challenges to administrative practices were also organized against administrative handling of a general legalization program and against agency implementation of a series of executive policies concerning the treatment of Haitian migrants arriving by sea. ${ }^{4}$

4 For a listing of the most important immigration-related class actions initiated during the $1980 \mathrm{~s}$ and 1990s, see Kawar (2015, 107-109). 
This particular configuration of formal rules and informal practices sets the stage for a quasi-ritualized performance of adversarial relations that each side understands and anticipates. In this performance of judicialized politics, immigrant rights advocates are positioned as strategists and negotiators who adopt an explicitly partisan stance. For instance, one veteran litigator is celebrated by his colleagues for being a "tenacious negotiator" who knew the government wanted to settle but nevertheless "kept asking for more". ${ }^{5}$ For their part, administrative officials characterize their adversaries as "agitators" intervening in agency operations. ${ }^{6}$ The litigation process thus transforms the administrative agency into a target. Lawyers repeatedly invoke the reputation of the agency as inept and potentially abusive. Characterized as prone to incompetence and excess, the agency is isolated from the larger apparatus of the state and becomes simply an organization in need of legal oversight. While it is not surprising that advocates would adopt such a narrative, it is striking to see administrative officials narrate the agency's position in similar terms. As one longtime government official explained, "People have made a living out of litigating against the government. It's not so difficult. When an agency acts, you can always find someone who said a dumb thing with ten thousand employees". ${ }^{7}$ The tone of this comment, cynical about the agency's dilemma but also resigned, captures the extent to class action litigation amplifies adversarial relations between advocates and administrators.

In this adversarial performance, formalism is far from the stage. As one litigator explained, reflecting on an early class action settlement, "We didn't let formal legal obstacles stop us; we had a compelling narrative", ${ }^{8}$ Not only are lawyers focused on developing a compelling narrative, but they explicitly embrace the subjectivity of the litigation process. Rather than identifying legal expertise with logic and symmetry, lawyers challenging immigration policy operate in a zone where the absence of predictability is a potential source of advantage. Moreover, strength of position is closely related to level of resources. In the words of one legal activist who participated in several class actions targeting administrative practices, "We had a good chance of winning so long as we could garner the necessary resources to bring the lawsuits". 9 The resources of corporate law firms are particularly helpful, given the "massive" and wide-ranging discovery process. One veteran litigator described the decision to take on a case as a careful calculation:

When we take on cases, we consider five to six factors, such as what is the likelihood of success, how important are the rights at stake, how many people would the case impact, the availability of other resources to handle the case, what the case might cost to litigate and whether we have that much money in our accounts. ${ }^{10}$

Interview with Dan K., lawyer, in Boston (January 2012).

6 Interview with senior attorney, US Department of Justice, Immigration and Naturalization Service, Office of General Counsel, by telephone (June 2006).

7 Interview with senior attorney, US Department of Homeland Security, Office of Immigration Litigation, in Washington, DC (January 2012).

8 Interview with Dan K., lawyer, in Boston (January 2012).

$9 \quad$ Interview with Cheryl L., lawyer, by telephone (June 2006).

10 Interview with Peter S., lawyer, by telephone (May 2006). 
The individual clients in this type of class action litigation may not be identified until a case is on the verge of going to trial, since the national scale of many class action cases targets policies rather than individual outcomes.

From the time an immigration class action lawsuit is filed, both sides have their eye on the possibility of resolution through settlement. As one government attorney put it,

All class actions take on a life of their own after a while. They run their course. Either the plaintiffs will get something out of the case and will want to settle or the agency will get tired and want to settle. After a while they collapse under their own weight. ${ }^{11}$

District court judges are often a presence only in the background of these negotiations, and they maintain this background role in instances where a settlement or injunctive order gives attorneys a lead role in the process of implementing a judicially supervised remedy. Attorneys drive the process of implementation and set the bar for agency compliance. As one litigator explained, "It is implementation and monitoring that makes litigation meaningful". ${ }^{12}$ Immersed in the world of administrative implementation, the line between implementing an agreement and appropriating policy-making functions can be a thin one.

Overall, this process of contesting immigration policy in court amplifies adversarial relations between its participants. Litigators perceive government attorneys as assuming the role of gatekeepers at the door and thus unwilling to concede even when an agency decision was poorly reasoned. For their part, administrative officials acquire a keen awareness of litigators as adversaries. As one official asked rhetorically, "I mean, who's running the agency? The guy in the private sector who's threatening to sue you?"13 The government has repeatedly attempted to outflank legal activist efforts by persuading legislators to curtail the jurisdiction of courts to hear immigration class action lawsuits (see Kawar 2015, 114-126). Yet this particular mechanism for challenging immigration agency policies and practices remains a key feature of judicialized immigration politics.

\section{THE PERFORMANCE OF JUDICIALIZED POLITICS IN FRANCE}

In France, a close-knit network of jurists and legal scholars has likewise taken up the cause of contesting immigration policy in court since the 1970s, approaching their efforts through a self-understanding that is explicitly activist ("militant") and politically-engaged. Yet the institutional configurations, normative frameworks, and cultural traditions in which French immigration-centered legal activism operates have not supported the development of a mechanism akin to American class action litigation. France's legal system offers few tools for effectively enjoining the administration, and French judges are prohibited from reviewing administrative practices beyond what their jurisprudence classifies as administrative "decisions". More broadly, traditions separating the legal field from market relations militate against an opening to the pragmatic register of class action litigation, for fear that entrepre-

\footnotetext{
11 Interview with senior attorney, US Department of Homeland Security, Office of Immigration Litigation, in Washington, DC (January 2012).

12 Interview with Dan K., lawyer, in Boston (January 2012).

13 Interview with senior attorney, US Department of Homeland Security, Office of Immigration Litigation, in Washington, DC (January 2012).
} 
neurialism might lead lawyers to sacrifice their clients' needs for the sake of winning cases. Jurists associated with the immigration-specialized network of the Group for Information and Support of Immigrants (GISTI) are most comfortable adopting the Left's militant stance of disputing policies at the level of fundamental principles, and other legal activist efforts in France have tended to follow this model (Kawar 2015, 90-100; Israel 2003).

In this context, the recours pour excès de pouvoir before the Conseil d'Etat has become the mechanism of choice for invoking judicial oversight of immigration policymaking. The Conseil d'Etat not only serves as France's highest administrative jurisdiction but also hears abstract challenges to administrative regulations in first instance. Through the device of the recours pour excès de pouvoir, the Conseil d'Etat issued its celebrated 1978 decision that annulled a restrictive family reunification decree at a critical juncture in French immigration politics. Spurred on by this success, legal activists have petitioned the Conseil d'Etat over the past four decades to review numerous administrative decrees, circulars, and ordinances invoking not only basic rights to social protection but also formal principles of administrative legality. A handful of these cases have resulted in important declarations of principle, while numerous others have quashed immigration-related administrative regulations as ultra vires (Genevois 2009). Some legal commentators suggest that the Conseil d'Etat has been more concerned with raising its own profile and legitimacy in respect to other jurisdictions than in effecting substantive change in immigration policy (Lochak 2009; Abdelgawad and Weber 2008; Lochak 1993).

The device of the recours pour excès de pouvoir patterns how French immigrant rights advocates present immigration-related grievances for their judicial audience. As discussed above, US immigrant rights advocates have learned to accommodate the responsiveness of district court judges to compelling narratives and have presented their grievances accordingly. By contrast, their French counterparts are socialized into a different aesthetics of claims-making. As experienced immigrant rights advocates recognize, the values most prized by the "intellectual mechanics" of the Conseil d'Etat are legal coherence and consistency. Thus, rather than being combative, petitions to the Conseil d'Etat are typically explanatory in tone, adopting an abstract mode of argumentation appealing to their interlocutors' passion for filling in gaps and inconsistencies. As one lawyer explained: "Judges will not take you seriously or be favorably disposed if you are 'disagreeable.' The tone should always be moderate. The key is to go slowly with the Conseil d'Etat if you want to convince them to exercise control". ${ }^{14}$ This set of instructions for interaction with the Conseil d'Etat vividly encapsulates the combination of doctrinal, institutional, and political considerations that shape, and are in turn shaped by, French immigrant rights advocacy. Through the repeated process of organizing petitions to the Conseil d'Etat, advocates have learned to hide their "activist" identity and accommodate the expectations for moderation and circumspection held by adjudicators. This set of expectations encourages petitions that are not only brief but also avoid making claims which might be perceived as overly audacious. The fact that the Conseil d'Etat regularly acknowledges this accommodation on the part of GISTI's advocates reinforces these tendencies. Senior judges from the Conseil d'Etat praise the group for "knowing how to make a judicious use" of its procedures and characterize the results of this judiciousness as "clearly consequential" (Genevois 2009, 68). This template for how to engage the Conseil d'Etat, finessed over several decades,

14 Interview with Philippe W., lawyer, in Paris (June 2007). 
provides a model for younger immigrant advocates who are honored to be among the jurists "capable of litigating before the Conseil d'Etat". ${ }^{15}$ The achievement of this form of judicial engagement requires not only familiarity with the relevant law but also familiarity with the institution of the Conseil d'Etat and its standards for formal and formalist presentation. The increasing alignment of French law with European norms has not fundamentally altered these dynamics (Kawar 2014). French immigrant rights advocates continue to favor the abstract and generalized mode of argumentation in their regular interactions with the Conseil d'Etat, even as they adopt a more militant rhetoric when engaging with civil society groups and in their publications for a public audience.

Not only does the mechanism of the recours pour excès de pouvoir exert a moderating influence on the form and content of claims-making, but it also effectively blocks opportunities for confrontation between advocates and administrators. Once an immigration-related petition has been filed and a response from the administration received, the Conseil d'Etat assumes juridical agency over both fact-finding and legal research related to the dossier. ${ }^{16}$ This process develops outside the view of the parties and at a tempo that the judges determine for themselves. In other words, it is not the advocates who are authorized to depose administrators or review their files as part of discovery procedures; rather, all requests for evidentiary materials are handled by the investigating judges of the Conseil d'Etat. Moreover, the outcome of this process is not an injunction that constrains administrative practice and places blame on agency personnel. Instead, decisions of the Conseil d'Etat follow a strict template of listing the relevant normative considerations and then issuing a determination on whether the administrative circular in question should or should not be interpreted as exceeding the bounds of law. This oracle-like pronouncement may result in the quashing of an immigration regulation, but it will rarely open the administration to a flood of new claims from individual migrants or asylum seekers.

While the normative result of contesting immigration policies through the recours pour excès de pouvoir is typically limited to a targeted regulatory correction, the sustained performance of judicial supervision does nevertheless cultivate a dynamic of judicial-administrative interactions. The tenor of these interactions is instructive rather than intrusive, and it builds on the fact that the Conseil d'Etat formally has a dual role in advising the government on draft laws and regulations as well as in supervising the legality of enacted administrative policies. For the judges, these dual roles in the immigration policy domain are fundamentally complimentary:

Even if the work of our advisory section is purely advisory, the government has an incentive to follow this advice in order to avoid subsequent challenges before the adjudicative section. This is because the immigration texts are always contested by GISTI and the government knows this. It is still possible that a decree or circular will be annulled because the advisory section may not see all the problems, but our advice has substantial impact on the writing of the texts. ${ }^{17}$

From this point of view, the adjudication of immigration regulations enables the Conseil d'Etat to realize its broader role of encouraging administrators to explain, justify, and defend their policies in juridical terms. Rather than framing this dynamic in strategic terms, both judges

15 Interview with Serge S., lawyer, in Paris (June 2010).

16 For an ethnographic account of this process, see Latour (2002).

17 Interview with senior member of the Conseil d'Etat, Section Sociale, in Paris (May 2007). 
and administrators characterize their regular interactions as ensuring that the normative values of administrative law are realized. As one official emphasized, "The associations are doing their job by raising problems for the government to fix". ${ }^{18}$ While decisions of the Conseil d'Etat may create more work, insofar as the government is required to rewrite immigration regulations, administrators assess the practical effect of these actions as "relatively narrow". Whether it is preemptive or post hoc, the public stance of both judges and administrators is that judicial supervision keeps the system democratic, not in the American sense of majority rule but in a republican sense of operating for the public good. Viewed in terms of the interactions between judges and administrators, the judicialization of immigration politics in France is performed in the register of instruction and collective adherence to legal formalism. ${ }^{19}$

\section{THE PERFORMANCE OF JUDICIALIZED POLITICS IN SWITZERLAND}

In Switzerland, the door to routinized legal contestation of asylum matters was opened by the enactment of the 1981 Asylum Act, which while codifying bureaucratic practices in this domain also left federal authorities with significant implementing autonomy (Piguet 2013). Particularly since the 1990s, asylum has emerged as one of the most controversial and debated topics of the political agenda, with many legislative reforms adopted either in the Parliament or by citizens following a referendum (Parini and Gianni 2005). Much of this legislative activity has taken a restrictive tone, aiming to fight against perceived "abuses" of the asylum system (Miaz 2017a) and calling on those who implement the law to implement this restrictive agenda. Against this trend, a patchwork of various legal aid services organized at the cantonal level has operated to assure the legal defense of asylum seekers. ${ }^{20}$ Yet, in contrast to other countries, federal laws in Switzerland are immune to constitutional review (Rayner and Voutat 2014). Moreover, Swiss law offers no mechanisms either for collective litigation against administrative practice or for abstract judicial challenges to administrative policymaking. Facing these constraints, Swiss legal aid services have devoted their efforts to persistently challenging administrative decisions in individual asylum cases before the Federal Administrative Court, which is the only domestic court where it is possible to take such appeals.

Swiss written appellate procedure does not afford an open hearing that might serve as a forum for legal aid services to politicize asylum denials for a wider public audience. Nor do legal aid services have sufficient time and resources to defend everyone or to spend much time on each case, especially those assessed to have limited "chances of success". ${ }^{21}$ Therefore, with modest budgets and limited delays for appealing asylum determinations, legal aid services are not often in a position to develop extensive fact-finding in their appeals of asylum cases. Mainly, they rely on references to general country of origin information from independent

\footnotetext{
18 Interview with senior official, Ministry of Interior, Direction des Libertés Publiques et des Affaires Juridiques, in Paris (March 2007).

19 For a comparative perspective on formalism as a modality of judicialization, see Weiler (1994).

20 Most legal aid services are specialized services within one of the four national or regional charity and non-profit organizations that are often related to the humanitarian and social action of Churches or to trade-union federation and the Swiss socialist Party. See Miaz (2017a, 455-470).

${ }^{21}$ We refer to our interviews with lawyers and volunteers in legal aid services.
} 
sources such as the Swiss Refugee Council. Their heavy workload and tight deadlines also limit the ability of Swiss legal aid services to "invest" in making novel legal arguments in their appeals. ${ }^{22}$ Moreover, because legal aid representatives routinely interact with the administration and with the Court, their freedom to make audacious arguments or to systematically appeal every case is balanced against a concern for maintaining professional credibility. As a lawyer explains:

If we systematically appeal in the name of [our organization], we lose credibility and, once we really have an important case, judges will not make the distinction and tell themselves: oh, this is [organization], they systematically appeal. So, it is not important..$^{23}$

As we see, concern for credibility urges against taking aggressive litigation positions.

Nevertheless, the persistent commitment of Swiss legal aid services to appealing individual cases, and the massive cumulative volume of these appeals nationally, has left a lasting influence, through the role of specialized adjudicatory bodies for handling asylum questions. ${ }^{24}$ Since 2007, two specialized divisions of the Federal Administrative Court have devoted their work specifically to asylum matters and have demonstrated substantial interest in formulating a jurisprudence to address issues raised in their sizable docket of appeals (Tanquerel et al. 2011). Caselaw has specified legal concepts and procedures in asylum matters, both on substantive issues - for example, the notion of persecution - as well as procedural ones, such as evidence and credibility issues. Yet perhaps the most notable aspect of this evolving "sophistication of law" (see Miaz 2017a and 2017b) has involved judicial handling of questions related to the motives and countries of origin of asylum seekers, areas where the Court has enunciated general rules that apply to broad categories of applicants.

This judicial rulemaking has an appreciable influence on the implementation practices of the federal administrative body charged with deciding asylum claims in first instance, the State Secretariat for Migration. Those charged with determining asylum claims in first instance deal with a constant "threat of appeal" against their decisions, especially when they delay in adapting their practice to the Court's evolving jurisprudence concerning, for example, whether removals to a given country, regardless of varying conditions, are reasonable. ${ }^{25}$ Ultimately, if the administration repeats the same "mistake" for long enough, it may risk the embarrassment of a more sweeping censure from the Court for failing to uphold general legal principles. ${ }^{26} \mathrm{In}$ these instances, the administration's substantive shift in practice when faced with such direct criticism is revealing of its tendency to avoid open confrontation.

22 Interview with a lawyer, SAJE (legal aid service), Lausanne, June 2013.

23 Interview with a lawyer, ELISA (legal aid service), Geneva, December 2012.

24 The Asylum Appeal Commission was created in 1992 as an independent judicial board specialized in asylum matters (Pärli 2019). When the Federal Administrative Court was created in 2007 after a reform of judicial institutions, the Asylum Appeal Commission became Divisions IV and V of the Federal Administrative Court.

25 Interview with a middle-manager, SEM, September 2011. According to the Foreign Nationals and Integration Act (FNIA), "enforcement [of removal order] may be unreasonable for foreign nationals if they are specifically endangered by situations such as war, civil war, general violence and medical emergency in their native country or country of origin". (art. 83 paragraph 4 FNIA). So, the unreasonableness of the removal is related to humanitarian reasons, but also to "vulnerability" of the persons and medical grounds.

26 Interview with an asylum caseworker, SEM, July 2012. 
At the same time, the administration has responded to judicial rulemaking by taking the initiative to develop its own secondary implementation norms (Miaz 2017b, 2019), ${ }^{27}$ which provide internal guidelines regarding the adjudication of asylum demands for the main countries of origin. These administrative "practice" guides consider not only legislation and caselaw, but also incorporate evolving country of origin information that the administration collects and compiles itself. Setting forth guidelines on country of origin conditions not only reduces vulnerability to judicial correction by advancing the goal of administrative consistency; it also operates as a mechanism for the State Secretariat for Migration to assert its own contrasting expertise in this area. While not explicitly confrontational, this assertion of administrative expertise offers an indirect means of providing the Federal Administrative Court with new arguments or new country of origin information. As one official explained:

Because it can happen, sometimes, that we consider that we should redirect the practice for a country. So, we try to make decisions that deviate a little bit from the case law and precisely to also perhaps lead the Federal Administrative Court to review its case law a little, because we work with countries where the situation is changing and there are sometimes needs to adapt to these changes. ${ }^{28}$

Empowered to act strategically by its own body of arguably more current knowledge of the international context, the State Secretariat for Migration responds to judicial rulemaking by counterposing alternative guidelines to country of origin conditions in asylum cases.

Significantly, in this action-reaction dynamic between competing sources of expertise administrative and judicial - the strategy of the State Secretariat for Migration is not acting alone. Because asylum is a polarized political issue, Members of Parliament and Federal Councilors routinely inveigh against the consequences of the Court's jurisprudence and against what some of them view as judicial activism on asylum. ${ }^{29}$ These public political polemics have particular resonance in a context where the administration is applying a law voted by referendum and thus "wanted by the people", and they provide support for the administration to take the position that their practices must accommodate "the popular will". ${ }^{30}$ This stance was in evidence, for instance, when right-wing politicians criticized judicial caselaw on country conditions in Eritrea, calling not only for tightening the Asylum Act but also pushing the administration for a change of practice. ${ }^{31}$ Tellingly, the State Secretariat for Migration aligned itself with this legislative stance by producing new country of origin information, and it again strengthened its practice after legislators organized a so-called "fact-finding mission"

\footnotetext{
27 For a definition of this term, see (Lascoumes, 1990).

28 Interview with an asylum caseworker, SEM, November 2011.

29 They denounce practices and jurisprudence that are considered "too generous", making Switzerland "too attractive", or leading to "abuses". See, e.g., the parliamentarian question: Hans Fehr (Swiss People’s Party), “Asylrekurskommission macht Politik” (04.1006) March 2, 2004.

30 Interview with a middle-manager, SEM, March 2012.

31 In a parliamentary motion, Hans Fehr (Swiss People's Party) urged the government to make Switzerland less attractive by making sure that "no Eritrean nationals receive asylum". Hans Fehr, "Aucun droit d'asile accordé aux migrants érythréens" (15.3566), June 16, 2015, available at:

https://www.parlament.ch/fr/ratsbetrieb/suche-curia-vista/geschaeft?AffairId=20153566, accessed July 8, 2019. See also parliamentary interpellation of Jasmin Hutter-Hutter (Swiss People's Party), "Jusqu'où ira-t-on dans les admissions en masse de requérants d'asile érythréens?" (08.3353), June 12, 2008. See also Stünzi (2014).
} 
to Eritrea to focus public attention on this case. ${ }^{32}$ Facing this volley of new "facts" in the administration's practice guidance, the Federal Administrative Court adapted by changing its own interpretation, with the effect that nationals of Eritrea are relatively less protected against removal than under the prior caselaw. Yet there is every indication that the match of expert competences will continue, as legal aid services are now trying to change this jurisprudence by presenting the Court with Eritrean cases in which arguably-unreasonable administrative denials may potentially call into question the appropriateness of the current rule.

These dynamics combine to create a distinct register of judicialized asylum politics that centers on a competitive match-up of contrasting sources of state expertise and argumentation in which open confrontation is avoided, even as each side asserts its relative competence. The Federal Administrative Court and the State Secretariat for Migration are the primary players in this game. At the same time, the contributions of a wider set of actors, including legal aid services and members of parliament, should not be overlooked. Their divergent framings of asylum controversies contribute distinct substantive content to the iterative policy interdependence chain (see Doumoulin and Roussel 2010), shaping the rules and guidelines iteratively formulated by judicial and administrative jurisdictions.

\section{CONCLUSION: A NEW LEGAL REALIST APPROACH TO THE JUDICIALIZATION OF IMMIGRATION POLICYMAKING}

The foregoing three case studies from the US, France and Switzerland examined participants' shared understandings of what is happening when immigration policy implementation is judicialized. The analysis of these cases adopted a relational and pragmatist approach in studying judicialized policymaking. As we show, the register through which judicialized immigration politics is enacted varies substantially across our three settings. In the US, the judicialization of immigration policy centers on open confrontation between litigators and administrators, with the public performance of class action lawsuits linked to wider debates about liberal advocacy and the legacy of the civil rights movement. In France, the use of recours pour excès de pouvoir by a network of militant lawyers and legal scholars has allowed them to challenge immigration policies at the level of fundamental principles. In this context, the judicialization of immigration politics is performed in the register of instruction and collective adherence to legal formalism. Finally, in Switzerland, the judicialization of asylum policy operates through contestation of individual decisions and centers on competing assertions of expertise, particularly over country conditions information. The state authorities at the center of this iterative action-reaction interplay of expertises rarely assume an openly confrontational tone towards one another, even as other actors engaged in the chain of asylum policymaking do occasionally assume more impassioned stances as they operate between these two authorities that finally decide.

The analysis in this chapter provides empirical support for recent calls to move beyond a judicialization framework wedded to interbranch conflict in order to embrace the hetero-

32 Like Damian Rosset and Tone Liodden underlines it well, this suggests that country of origin information (COI) "may function as a potential means of deterrence and that the boundaries between COI and policy goals blur easily, such that the production of knowledge becomes a site of politicalnegociation" (Rosset and Liodden 2015, 26). 
geneous and varied set of actors who may mobilize legal repertoires or have recourse to the judicial arena (Dumoulin and Roussel 2010). We build upon this framework by highlighting not only the shared repertoires of argumentation associated with judicialized politics but also less-intellectualized performative repertoires set in motion by judicial engagements. Our analysis thus marks a departure from so-called "realist" empirical studies which conceptualize judicialization as a strategic struggle between actors in competing branches of government. ${ }^{33}$ The sociolegal approach in this chapter not only eschews formalist legal analysis but also elaborates an interpretivist empirical stance that is clearly distinct from the objectivism and epistemological positivism of realist-behavioralist models of judicialization. Indeed, what our interpretive analysis reveals is that judicialization may in some contexts be associated with the multiplication of expertise, but even in these circumstances the dynamics of legal contestation are not only cerebral but also affective. This insight is consonant with a tradition of judicialization scholarship that conceptualizes judicial procedures as assemblages of cultural referents available for social and political mobilization (see Sterett 2016; Kawar 2014; Sieder 2013). In carefully tracing these dynamics, our aim is to render observable the full range of actors in each particular field of law-in action as well as the registers of interaction among them (see Scheffer 2010).

In addition, our analysis demonstrates the extent to which registers of judicialized immigration and asylum politics are not only context-specific but also self-reinforcing. At one level, differences between the national case studies reflect divergent legal opportunities and constraints, a framework well-established within the sociolegal scholarship on judicialization (see, for example, Vanhala 2012; Andersen 2009; Hilson 2002). Yet our three case studies collectively highlight the extent to which these patterns of interaction result not from any single structure but rather are assembled through the practices of multiples actors embedded in a specific historical, political and legal lifeworld. These actors are not only courts, parliaments and governments, but also administrations, advocacy networks, and other law intermediaries whose practices respond to, anticipate and impact upon each other, not only strategically but also affectively. The identity of the actors, the meaning of their respective roles, and their relations with each other are not only part of the register of judicialized politics but are themselves constituted by its performance.

What implications do these findings hold for future legal scholars and practitioners drawn to intervene in the immigration policymaking domain? First, the discovery of multiple registers of judicialized immigration politics means that scholars cannot assess the judicialization of immigration in the abstract, without investigating empirically what judicial interventions mean to the administrators and advocates invested in these cases. As we show, it is less the rule that matters than the relation of social actors to these rules and the uses they make of them. Judicialization is not simply a shift in normative or political authority to the courts, but nor is it an interactive game that can be modeled in the abstract. The meaning of this culturally productive process, which shapes how actors understand their roles and respond to each other, cannot be separated from context.

33 While the behavioralist instrumentalism of these models is reminiscent of earlier generations of Legal Realist scholarship, formal modeling of judicialization operates at such a high level of generality and with such a constraining set of assumptions that is unlikely to be useful to legal scholars or practitioners wishing to understand how policy processes work and are experienced day-to-day. 
Second, legal practitioners must appreciate and contend with the strikingly different forms by which law may be mobilized by social and political actors. Empirical study across national contexts interrupts linear narratives of progress so often associated with rights-based mobilizations. At the same time, exploring the wide range of registers for contesting immigration policy in court may have the benefit of disrupting established routines and encouraging experimentation with new and potentially productive forms of advocacy.

Third, the notion of "translation" between empirical study and policy-oriented scholarship, which lies at the center of the New Legal Realist program, should be understood as working in both directions. We know that law reform can and should be informed by empirical findings if it is to be efficacious. However, the examination of judicialized immigration politics in this essay offers a reminder that law reform is also an "actant" in its own right. Advocacy has propelled immigration policy changes in some instances, but the local ontologies instantiated through these interactions have also conditioned particular types of administrative responses. In other words, legal expertise is deeply implicated in constructing the social reality of the group relations with which it engages. The question to ask is how legal expertise might be better integrated into social research on immigration, i.e. into inquiries about how non-citizens, public officials, and the broader public understand the politics of immigration. Rather than resting outside the scene, law reform efforts can then enter into more dialogic association with knowledge of how law is experienced.

\section{REFERENCES}

Abdelgawad, E., and Weber, A. 2008. The Reception Process in France and Germany. In Keller, H. and Stone Sweet, A. (eds) A Europe of Rights: The Impact of the ECHR on National Legal Systems, 107-164. Oxford: Oxford University Press.

Andersen, E.A. 2009. Out of the Closets and into the Courts: Legal Opportunity Structure and Gay Rights Litigation. Ann Arbor: University of Michigan Press.

Brodkin, E. 2013. Street-Level Organizations and the Welfare State. In Brodkin, E. and Marston, D. (eds) Work \& the Welfare State. Street-Level Organizations and Workfare Politics, 17-34. Washington: Georgetown University Press.

Coutin, S. 2006. Cause Lawyering and Political Advocacy: Moving Law on Behalf of Central American Refugees. In Sarat, A. and Scheingold, S. (eds) Cause Lawyers and Social Movements, 101-119. Stanford: Stanford University Press.

Cummings, S. 2007. The Internationalization of Public Interest Law. Duke Law Journal 57: 891-959.

Dembour, M-B. 2015. When Humans Become Migrants. Oxford: Oxford University Press.

Dumoulin, L., and Roussel. V. 2010. Chapitre 9. La judiciarisation de l'action publique. In Borraz, O. and Guiraudon, V. (eds) Politiques publiques 2, 243-63. Paris: Presses de Science Po.

Erlanger, H., Garth, B., Larson, J., Mertz, E., Nourse, V., and Wilkins, D. 2005. Forward: Is it Time for a New Legal Realism? Wisconsin Law Review 2005(2): 335-363.

Gambino, L. 2018. 'The Civil Rights Issue of Our Time': How Dreamers Came to Dominate US Politics. The Guardian, January 27. https://www.theguardian.com/us-news/2018/jan/27/the-civil-rights-issue -of-our-time-how-dreamers-came-to-dominate-us-politics, accessed July 8, 2019.

Genevois, B. 2009. Le GISTI: Requérant d'Habitude? La Vision du Conseil d'Etat. In GISTI (ed.) Défendre la Cause des Etrangers en Justice, 65-79. Paris: Dalloz.

Gessner, V., and Thomas, J. 1988. Socio-Legal Research and Policy Studies: A Review of the Issues. Law and Policy 10(3): 85-96.

Glenn, H.P. 1991. Comparative Law, Immigration and Human Rights. African Journal of International and Comparative Law 3: 668-679.

Hailbronner, K. 1998. European Immigration and Asylum Law under the Amsterdam Treaty. Common Market Law Review 35: 1047-1067. 
Hailbronner, K. 2007. Detention of Asylum Seekers. European Journal of Migration and Law 9(2): 159-172.

Hansen, R., Martin S., Schoenholtz, A., and Weil, P. 2000. Report on the Workshop on Refugee and Asylum Policy in Practice in Europe and North America. Georgetown Immigration Law Journal 14(3): 801-814.

Hilson, C. 2002. New Social Movements: The Role of Legal Opportunity. Journal of European Public Policy 9(2): 238-255.

Israel, L. 2003. Faire Emerger Le Droit Des Etrangers En Le Contestant, Ou L'histoire Paradoxale Des Premieres Annees Du Gisti. Politix 16, no. 62 (2003): 115-144.

Kawar, L. 2011. Legal Mobilization on the Terrain of the State: Immigrant Rights Practice in Two National Legal Fields. Law and Social Inquiry 36(2): 354-387.

Kawar, L. 2014. Commanding Legality: The Juridification of Immigration Policy Making in France. Journal of Law and Courts 2(1): 93-116.

Kawar, L. 2015. Contesting Immigration Policy in Court: Legal Activism and Its Radiating Effects in the United States and France. New York: Cambridge University Press.

Knorr Cetina, K. 1999. Epistemic Cultures: How the Sciences Make Knowledge. Cambridge: Harvard University Press.

Lascoumes, P. 1990. Normes Juridiques et Mise en Euvre des Politiques Publiques. L'Annee Sociologique 40:43-71.

Latour, B. 2002. La Fabrique du Droit. Une Ethnographie du Conseil d'Etat. Paris: La Découverte.

Law, A. 2010. The Immigration Battle in American Courts. New York: Cambridge University Press.

Lipsky, M. 2010. Street-Level Bureaucracy, 30th Ann. Ed.: Dilemmas of the Individual in Public Service. New York: Russell Sage Foundation (1st Ed. 1980).

Lochak, D. 1993. Quelle Legitimité pour le Juge Administratif? In C.U.R.A.P.P. (ed.) Droit et Politique, 141-157. Presses Universitaires de France.

Lochak, D. 2009. Trente Ans de Contentieux à l'Initiative du GISTI. In GISTI (ed.) Défendre la Cause des Etrangers en Justice, 43-64. Paris: Dalloz.

Miaz, J. 2017a. Politique d'asile et Sophistication Du Droit. Pratiques Administratives et Défense Juridique Des Migrants En Suisse (1981-2015). PhD dissertation. University of Lausanne and University of Strasbourg.

Miaz, J. 2017b. From the Law to the Decision: The Social and Legal Conditions of Asylum Adjudication in Switzerland. European Policy Analysis 3(2): 372-396.

Miaz, J. 2019. Le Droit et Ses Médiations. Pratiques d'instruction Des Demandes d'asile et Encadrement Institutionnel Des Décisions. Politique et Sociétés 38(1): 71-98.

Money, J. 2018. Comparative Immigration Policy. Oxford Research Encyclopedia of International Studies.

Morris, M. 1984. Immigration--The Beleaguered Bureaucracy. Washington, D.C.: Brookings Institution.

Motomura, H. 1990. Immigration Law after a Century of Plenary Power: Phantom Norms and Statutory Interpretation. Yale Law Journal 100: 545-613.

Neuman, G. 1990. Immigration and Judicial Review in The Federal Republic of Germany. N.Y.U. Journal of International Law and Politics 23: 35-85.

Nourse, V., and Shaffer, G. 2009. Varieties of New Legal Realism: Can a New World Order Prompt a New Legal Theory? Cornell Law Review 95(1): 61-137.

Parini, L., and Gianni, M. 2005. Enjeux et Modifications de La Politique d'asile En Suisse de 1956 à Nos Jours. In Mahnig, H. (ed) Histoire de La Politique de Migration, d'asile et d'intégration En Suisse Depuis 1948, 189-252. Zurich: Editions Seismo.

Pärli, J. 2019. Legal, Illegal... - Wer Genau? Die Schweizer Asylbewegung Und Der Streit Um Das Recht 1973-1992. Zeitschrift für Rechtssoziologie 39(2): 177-203.

Parthasarathy, S. 2017. Patent Politics. Chicago: University of Chicago.

Piguet, É. 2013. L'immigration en Suisse: soixante ans d'entrouverture (3rd edition). Lausanne: Presses Polytechniques et Universitaires Romandes.

Rayner, H., and Voutat, B. 2014. La judiciarisation à l'épreuve de la démocratie directe. Revue Française de Science Politique 64(4): 689-709.

Rosset, D., and Liodden, T. 2015. The Eritrea Report: Symbolic Uses of Expert Information in Asylum Politics. Oxford Monitor of Forced Migration 5(1): 26-32. 
Scheffer, T. 2010. Adversarial Case-Making: An Ethnography of English Crown Court Procedure. London: Brill.

Sieder, R. 2013. Legal Cultures and the (Un)rule of Law: Indigenous Rights and Juridification in Post-Conflict Guatemala. In Couso, J., Huneeus, H., and Sieder, R. (eds) Cultures of Legality: Judicialization and Political Activism in Latin America, 161-181. New York: Cambridge University Press.

Sterett, S. 2016. Legal Mobilization and Juridification: Migration as a Central Case. Law \& Policy 38(4): 273-279.

Stünzi, R. 2014. Les Mesures Dissuasives et Leurs Limites: Données Empiriques et Réflexions Au Sujet Du Nouvel Art. 3 al. 3 LAsi et de La Suppression Des Demandes d'asile En Ambassade. Asyl. Schweizerische Zeitungschrift für Asylrecht und Praxis // Revue Suisse pour la pratique et le droit d'asile 29(4): 26-33.

Tamanaha, B. 2017. A Realistic Theory of Law. New York: Cambridge University Press.

Tanquerel, T., Varone, F., Bolkensteyn, A., and Byland, K. 2011. Le Contentieux Administratif En Suisse: Une Analyse Empirique. Genève: Schulthess.

Traweek, S. 1992. Beamtimes and Lifetimes: The World of High Energy Physicists. Cambridge: Harvard University Press.

Vanhala, L. 2012. Legal Opportunity Structures and the Paradox of Legal Mobilization by the Environmental Movement in the UK. Law \& Society Review 46(3): 523-556.

Weiler, J. 1994. A Quiet Revolution: The European Court of Justice and Its Interlocutors. Comparative Political Studies 26 (January): 510-534. 